Check for updates

Cite this: RSC Adv., 2019, 9, 25518

Received 30th April 2019

Accepted 26th June 2019

DOI: $10.1039 / c 9 r a 03229 k$

rsc.li/rsc-advances

\section{Polyphenols of Chinese skullcap roots: from chemical profiles to anticancer effects}

\author{
Lingchong Wang, (D) $\dagger^{\mathrm{ab}}$ Dapeng Zhang, $\dagger^{\mathrm{bc}}$ Ning Wang, ${ }^{\mathrm{b}}$ Sha Li, ${ }^{\mathrm{b}}$ Hor-Yue $\operatorname{Tan}^{\mathrm{b}}$ \\ and Yibin Feng ${ }^{\star b}$
}

Great efforts have been made to identify the principle bioactive constituents of Chinese herbs and to unravel the molecular mechanisms behind their anticancer effects. Scutellaria baicalensis (Huangqin or Chinese skullcap) is a widely consumed herbal medicine and has been historically used in anticancer therapy in China and other countries. Chinese skullcap generates many active chemicals in the root and is abundant in polyphenols, which act as its anti-cancer ingredients. It contains around 53 polyphenols in total: 50 flavonoids and 3 stilbenes. The polyphenols have similar chemical structures since they are derived from similar biochemical synthetic pathways. According to the literature, as the active chemicals of the skullcap root, 18 polyphenols exhibit evident anticancer activities. They can be developed not only as novel candidates and precursors in anticancer drug screening, but also as important tools and agents in cancer pharmacology. We comprehensively elaborated the anticancer pharmacological properties of crude polyphenolic extracts and 12 other single compounds excluding the six well-known polyphenols, i.e., baicalein, baicalin, wogonin, wogonoside, chrysin and verbascoside. In this review, we also discussed the possible mechanisms of the anticancer effect of several skullcap polyphenols. Overall, this paper provides a unique path to understand the anticancer properties of Chinese skullcap as well as guidance to find novel anticancer drugs from a natural polyphenolic reservoir.
${ }^{a}$ School of Pharmacy, Nanjing University of Chinese Medicine, Nanjing City, Jiangsu Province, 210023, P. R. China. E-mail: 993wlc@njucm.edu.cn

${ }^{b}$ School of Chinese Medicine, LKS Faculty of Medicine, The University of Hong Kong, Pokfulam, Hong Kong SAR, P. R. China. E-mail: yfeng@hku.hk; ckwang@hku.hk; lishaha@hku.hk; hyhtan@hku.hk; Fax: +86-852-2872-5476; Tel: +86-852-39176482
'First Affiliated Hospital of Guangzhou Medical University, Guangzhou City, Guangdong Province, 510120, P. R. China. E-mail: dapeng096@163.com

$\dagger$ Authors with same contributions.

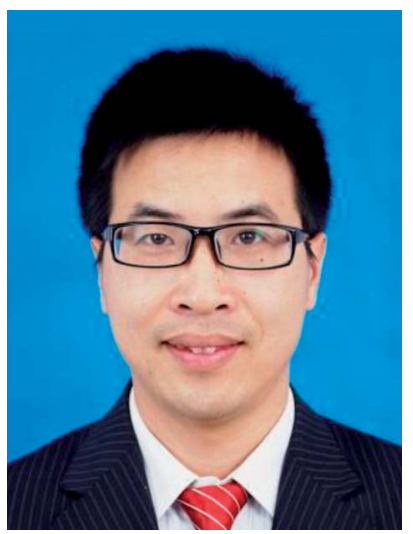

Lingchong Wang received his B.S. (2003) and PhD (2008) in marine biological science from the Ocean University of China. He worked for the Nanjing University of Chinese Medicine as an Assistant research fellow from 2008 to 2012 and then, he was promoted to Associate Professor. He was a visiting scientist at the University of Hong Kong from 2018 to 2019 in cooperation with Dr Feng for herbal ingredient screens for cancer and hepatic diseases. His research interests include product development and designing new dosage forms, isolation, purification and structural elucidation of active ingredients from natural resources. He has authored 12 patents and $100+$ papers.

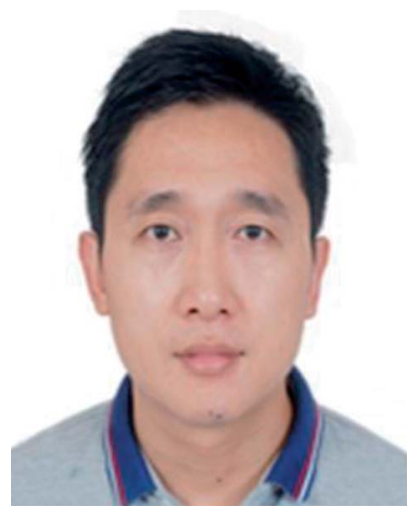

Dapeng Zhang received his B.S. in 2002 from Henan TCM University, M.S. in 2005 from Guangzhou TCM University, and $\mathrm{PhD}$ in 2008 in Integrated traditional Chinese and western medicine from Guangzhou TCM University. After joining the First Affiliate Hospital of Guangzhou Medical University as a lecturer in 2008, he was promoted to Associate Professor (2012). He was a visiting scholar at the University of Hong Kong in 2018 (research group of Dr Feng). His research interests include natural drug immunopharmacology and the interactions between gut microbiota and natural products. 


\section{Introduction}

Cancer is a complex disease involving excessive proliferation of abnormal cells, which may grow malignantly in specific tissues until tumor formation. The occurrence and development of cancer undergo a series of progressive stages from the uncontrolled proliferation and division of cells to their spread and metastasis. Cancer might be the most refractory disease, and its mortality increases year by year. It is urgent to find efficient drugs for various cancers. Traditional Chinese medicine (TCM) is a good choice for the screening of anticancer agents because there is a long history of using herbal medicine in cancer therapy. TCM has the features of multi-component chemistry and multi-targets in terms of pharmacology; therefore, it is suitable for cancer therapy, considering the complex pathogenesis. Many Chinese patients are willing to use TCM products to slow down the cancer symptoms. ${ }^{1}$

Polyphenols, secondary metabolites of plants, are perhaps the most universal ingredients of many herbs with diverse structures and bioactivities. ${ }^{2}$ Herbal polyphenols can be classified into flavonoids, hydroxycinnamates, hydroxybenzoic acid esters, coumarins, xanthones, chalcones, anthraquinones, lignins and lignans, etc. These chemicals can be developed as drug candidates from the active confirmation of in vitro screens or in vivo evaluations. An increasing number of modern studies indicate that herbal polyphenols may play an important role in cancer prevention or treatment. Some herbal polyphenols can block the key biochemical pathways of carcinogenesis., ${ }^{\mathbf{3} 4}$

Scutellaria baicalensis Georgi, also known as Chinese skullcap or Huangqin, is a perennial herb of the Lamiaceae family. ${ }^{5}$ Its root is one of the 50 fundamental herbs used in the formulations of TCM. ${ }^{6,7}$ Skullcap root has been authorized in the treatment of jaundice, hepatitis, and diarrhea and infections of the respiratory and gastrointestinal tracts in China for

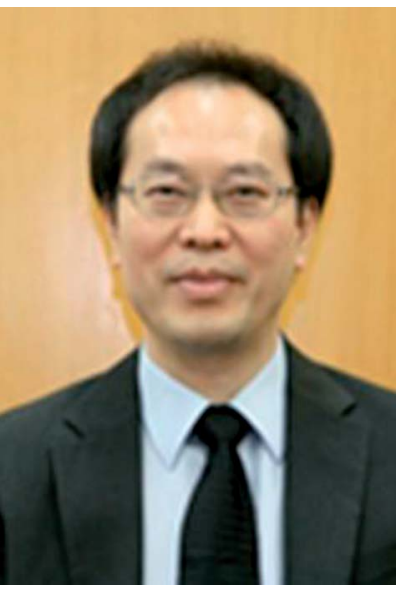

Yibin Feng was awarded his B.S. by the Yunnan University of Chinese Medicine (1983) and PhD in Molecular Medicine by the Hokkaido University in Japan (1997). He did postdoctoral research in Molecular Pharmacology at the Hokkaido University in 1999. He is currently an Associate Professor cum Associate Director (education) in the School of Chinese Medicine, University of Hong Kong. He has published over 400 publications that explore scientific evidence for herbal medicines in the prevention and treatment of cancer diseases. He was listed as one of the HKU scholars in the top 1\% by 2018 Essential Science Indicators. He has served as an advisor/ expert committee member in government agencies, professional bodies and WHO. more than 2000 years. $^{8}$ Recent clinical applications have involved Chinese skullcap in the treatment of many diseases including inflammation, ${ }^{\mathbf{9}, \mathbf{1 0}}$ hypertension, ${ }^{\mathbf{1 1}}$ cardiovascular disease $^{\mathbf{1 2}}$ neurodegeneration ${ }^{\mathbf{1 3}}$ and tumors. ${ }^{7}$ The therapeutic roles of Chinese skullcap against diseases are closely related to its antipyretic, antioxidant, anti-inflammatory, antimicrobial, and antitumor pharmacological actions. ${ }^{\mathbf{1 4 - 1 7}}$ The antitumor effect of skullcap as TCM is widely recognized because of its historical clinical applications as a single component or in formulations for treating cancerous diseases. ${ }^{7}$ Chinese skullcap is abundant in flavonoid polyphenols as its anti-cancer ingredients, including baicalein, wogonin and oroxylin A, as well as the glycosidic derivatives, namely, baicalin, wogonoside and oroxylin-A-7-O-glucuronide. ${ }^{18}$ These flavonoids share a primary molecular skeleton and are very similar in structure since they originate from the same biosynthetic pathway. ${ }^{19}$ As notable polyphenolic molecules, they are considered as important anticancer candidates in drug screens, novel emerging additives in the treatment of various diseases, and important tools and agents in cancer pharmacology. The chemicals baicalein, wogonin, baicalin and wogonoside derived from Chinese skullcap may block the signal transduction of cancer by controlling the nuclear factor- $\kappa \mathrm{B}(\mathrm{NF}-\kappa \mathrm{B})$ signaling pathway, protein tyrosine kinase (PTK) pathway and mitogen-activated protein kinase (MAPK) signaling pathway. ${ }^{6}$

We reviewed the anticancer effects of the $S$. baicalensis extract and some well-known polyphenols (wogonin and baicalin); we also discussed the underlying molecular mechanisms ranging from in vivo studies to clinical applications. ${ }^{7}$ However, previous research is still insufficient to understand the complete therapeutic roles of Chinese skullcap against cancers, considering the diversity of polyphenols and biased discussions in pharmacology. In this review, we first retrieved all the polyphenol compounds derived from skullcap roots and categorized them properly in terms of their structures and anticancer effects. A network pharmacology approach was used for the certification of targets and pathways of each polyphenol in cancer pathogenesis but unfortunately, no useful information was obtained. Herein, we mainly summarized the results of the anti-cancer studies on polyphenols in skullcap roots conducted over the past 20 years. This review also discussed the possible mechanisms of some single polyphenols interfering with carcinogenesis or cancer progression. Moreover, this review roughly explored the structure-activity relationships of Chinese skullcap polyphenols from the viewpoint of new drug discovery and development. As a technical roadmap, Fig. 1 illustrates the intent and procedure of this investigation.

\section{Polyphenol compounds in Chinese skullcap root}

More than 5000 reports have been published on the bioactivity and chemistry of herbs from the genus Scutellaria, and most are clearly relevant to polyphenol compounds. Some papers estimated 30-50 polyphenols to be present in Scutellaria species, but the actual data revealed far more than this estimation. The 


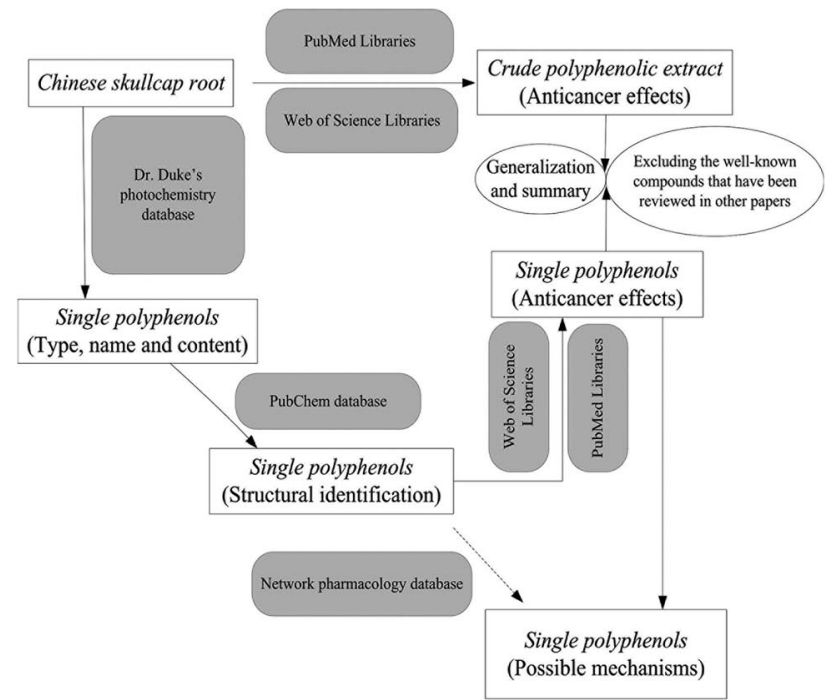

Fig. 1 The motive, conception and technical route of this review.

Russian phytochemist Karimov summed up all the flavonoids (polyphenols) in the species of Scutellaria genus ${ }^{20}$ and listed 301 well-defined polyphenol compounds: 182 flavonoids, 70 flavanones, 9 flavonols, 10 chalcones, 13 flavonols, 5 isoflavones, 7 aflatoxins and 5 biflavonoids. Karimov also pointed out 131 polyphenols found in Chinese skullcap, and most were flavonoid compounds. ${ }^{20}$ However, the origins of the 131 polyphenols are uncertain because they might have been derived from the roots, stems, leaves, or even flowers of the plant. Then, we chiefly learned about the identifiable polyphenols in Chinese skullcap form Dr Duke's phytochemistry and ethnobotanical database resources (https://phytochem.nal.usda.gov) and the search was limited to root-originating polyphenols. As a result, 53 compounds were obtained in total: 50 flavonoids and 3 stilbenes (Table 1). The 50 flavonoids were further divided into two groups: 44 flavones and 6 flavanones. All 53 polyphenols were further confirmed by comparison with the report of Karimov. ${ }^{20}$

The polyphenols of Chinese skullcap were ranked according to their contents in the root. Baicalin, baicalein, wogonoside, oroxylin-A-7-O-glucuronide, wogonin and chrysin-6- $C$ - $\alpha$-L-arabinoside-8- $C$ - $\beta$-D-glucoside were abundant in Chinese skullcap since their contents were more than $0.2 \%$ in the root. Basically, these compounds, especially baicalin and baicalein, contribute to the major clinical activities of Chinese skullcap. Baicalein can be chemically classified as a $(5,6,7)$-trihydroxyl-substituted flavone, while baicalin is its $7-O-\beta$-D-glucuronide derivative. Other baicalein glycosylated homologues, namely, oroxin-A and baicalin-methylate were also detectable in the root in small amounts. Wogonoside is the glycosylated derivative (7-O position) of wogonin, which is a 5,7-dihydroxyl and 8-methoxylsubstituted flavone. Wogonoside and wogonin were the third and fifth abundant polyphenols in the root, respectively. Moreover, the three wogonin glycosylated derivatives present in trace amounts were wogonin-7-O- $\beta$-D-glucuronide-methyl-ester,
wogonin-7-O- $\beta$-D-glucuronide and wogonin-5-O- $\beta$-D-glucoside. Oroxylin-A is an $O$-methylated flavone; however, its amount was far less than that of oroxylin-A-7-O-glucuronide and constituted only $1 \%$ proportion of the total compounds in the oroxylin-A family. The oroxylin-A family also includes oroxylin-A-7-Oglucuronide-methylester.

Chrysin and its derivatives are another type of flavones present in small or trace amounts. Six types of chrysin derivatives with glycosides at the $O$ - or $C$-position were detected in skullcap roots, representing the chrysin family as di-substituted flavones. Chrysin is not generally considered as a specific compound, indicating that the skullcap quality is due to its low amount and widespread presence in other species. However, many chrysin derivatives have been reported as having strong antitumor activity. ${ }^{41}$

The polyphenols found in skullcap roots in low or trace amounts included 25 other flavones, of which some are wellknown, while others may be new compounds with few reports about them. The well-known flavones viscidulin-III, rivularin, $4^{\prime}$-hydroxywogonin, norwogonin, viscidulin-II and scutevulin appeared at relatively high contents ( $>5 \mathrm{ppm})$, but panicolin, scutellarin, scutellarein, negletein, koganebananin, $2^{\prime}$-hydroxychrysin, koganebanain and andrographin appeared in undetectable amounts. Eight new flavones, named by their structure, are also listed in Table 1. These compounds indicate flavone diversity of skullcap root since flavones dominate all measurable polyphenols co-positioned in the herb. Flavone diversity is explained by the nature, quantity, and mutual arrangement of functional groups (Table 1). Based on the nature of substitution on the main backbone, all flavones of skullcap roots can be well classified and categorized.

Six flavanones were still detected in the Chinese skullcap root in spite of their relatively low contents. 2',6'-Dihydroxypinobanksin, dihydrohispidulin, and dihydrooroxylin-A are famous plant flavanones because they have strong in vitro or in vivo bioactivities. The presence of benzene-based compounds isolated from skullcap herbal medicine extended our knowledge on skullcap polyphenols since the chemical content is not limited to flavonoids. The three benzene compounds are verbascoside, leucosceptoside-A and 2,6,2', $4^{\prime}$-tetrahydroxy- $6^{\prime}$ methoxychalcone. Their content in the roots of $S$. baicalensis is low, and their structure can be accessed from Pubchem (https:// pubchem.ncbi.nlm.nih.gov).

All the identified compounds from the Chinese skullcap root were imported into Pubmed and Web of Science to further know their anti-cancer effect. As the most detected compounds in skullcap roots, 18 polyphenols exhibited unquestionable anticancer activity; these included baicalin, baicalein, chrysin, hispidulin, negletein, neobaicalein, norwogonin, oroxylin-A, scutellarein, scutellarin, verbascoside, wogonin, wogonoside, viscidulin-III and -II, dihydrobaicalein, oroxin-A and $4^{\prime}$-hydroxywogonin (as seen in Fig. 2 and Table 1). Among them, baicalein, baicalin, wogonin, wogonoside, scutellarein, scutellarein and oroxylin-A have been extensively reported. Other polyphenols have not been shown in anticancer research because they are low in content and difficult to obtain. Some of them are metabolites of the above-mentioned anticancer polyphenols; 
Table 1 The polyphenol compounds detected in the root of Chinese skullcap

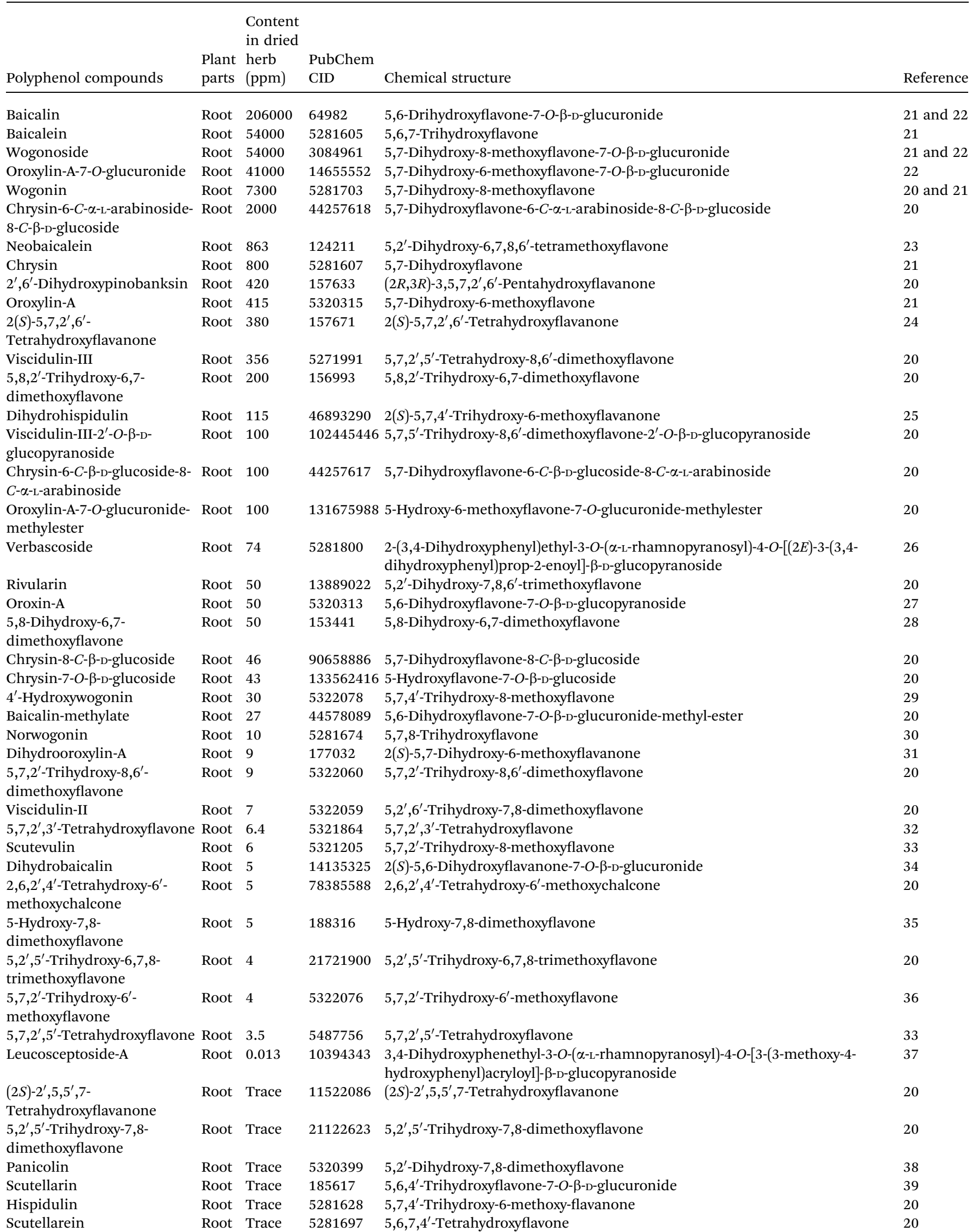




\begin{tabular}{|c|c|c|c|c|c|}
\hline Negletein & Root & Trace & 471719 & 5,6-Dihydroxy-7-methoxyflavone & 20 \\
\hline Koganebananin & Root & Trace & 5321865 & $5,7,2^{\prime}, 6^{\prime}$-Tetrahydroxyflavone & 40 \\
\hline 2'-Hydroxychrysin & Root & Trace & 5322064 & $5,7,2^{\prime}$-Trihydroxyflavone & 33 \\
\hline Chrysin-6-C- $\beta$-D-glucoside & Root & Trace & 90657677 & 5,7-Dihydroxyflavone-6-C- $\beta$-D-glucoside & 20 \\
\hline Andrographin & Root & Trace & 5318506 & 5-Hydroxy-7,8,2'-trimethoxyflavone & 20 \\
\hline $\begin{array}{l}\text { Wogonin-7-O- } \beta-\mathrm{D}- \\
\text { glucuronide }\end{array}$ & Root & Trace & 35755714 & 5-Hydroxy-8-methoxyflavone-7-O- $\beta$-D-glucuronide & 20 \\
\hline Wogonin-5-O- $\beta$-D-glucoside & Root & Trace & 44258554 & 7-Hydroxy-8-methoxyflavone-5-O- $\beta$-D-glucoside & 20 \\
\hline
\end{tabular}

they may also exhibit strong potentials and can be considered in new drug discovery in the anticancer field.

\section{Anticancer effects of the crude polyphenols of skullcap root}

The anticancer actions of skullcap are usually mentioned in academics, and many studies support adopting the skullcap polyphenols as potential agents for cancer intervention. The crude extracts isolated from skullcap roots, sometimes defined as polyphenol mixtures, are effective against many cancer types in experimental assays.Ye et al. showed that the polyphenolic extract of skullcap roots strongly inhibits the cell growth in many cancer cell lines, including PC-3, LNCaP, MCF-7, KM-12, HepG2, HCT-15, KB and SCC-25. ${ }^{42}$ The most prominent effects were displayed in the breast and prostate cancer cells PC-3, LNCaP, and MCF-7, for which the inhibition concentrations at $50 \%\left(\mathrm{IC}_{50}\right)$ were $0.9,0.52$ and $0.82 \mathrm{mg} \mathrm{mL}^{-1}$, respectively. ${ }^{42}$ Zhang et al. also verified the anticancer activity of a skullcap root decoction containing polyphenols against head and neck squamous cell carcinoma (SCC-25 and KB cells) in vitro. ${ }^{43}$ The $\mathrm{IC}_{50}$ value of the polyphenolic extract towards SCC-25 and KB cells was about $150 \mu \mathrm{g} \mathrm{mL} \mathrm{m}^{-1}$, but it was slightly less than the values of pure baicalein and indomethacin. ${ }^{43}$ Ye et al. later demonstrated that the skullcap polyphenolic extract might be a potent anticancer agent to cure prostate tumors. ${ }^{\mathbf{4 4}}$ The skullcap polyphenolic extract exerted dose- and time-dependent growing inhibition in the prostate cancer cell lines LNCaP and PC-3. It induced the apoptosis of LNCaP and PC-3, but the effect was more obvious for PC-3 cells due to the androgenindependent manner of inhibition. Incubation resulted in the reduction of prostaglandin $\mathrm{E}_{2}$ synthesis and direct inhibition of the cyclooxygenase-2 (COX-2) activity besides the expression of COX-2 protein in two cancer cell lines. ${ }^{44}$ Crude skullcap polyphenols decreased the production of prostate-specific antigen in LNCaP cells and finally caused a G(1) phase arrest in LNCaP cells as a result of the suppression of the cyclin D1 expression. In contrast, the sample inhibited cyclin-dependent kinase 1 expression and activity in PC-3 cells, ultimately leading to a G(2)/M cell cycle arrest. ${ }^{44}$ The oral administration of skullcap polyphenols (200 $\mathrm{mg}$ per $\mathrm{kg}$ per day) to tumor-bearing mice displayed $50 \%$ reduction in tumor volume after 7 weeks of treatment. $^{44}$ The baicalin-deprived-fraction (SbF1) of the skullcap polyphenolic extract exhibited a significant antiproliferative effect on breast cancer MCF-7 cells; the treatment with $100 \mu \mathrm{g} \mathrm{mL}^{-1}$ of $\mathrm{SbF} 1$ for $72 \mathrm{~h}$ could inhibit $81.6 \%$ of cell growth. ${ }^{45}$ Crude skullcap polyphenols, as an ethanol extract, generated selective toxicity to human lung cancer cell lines A549, SK-LU-1 and SK-MES-1 in comparison with normal lung fibroblasts in a cytotoxicity test. In contrast, sole baicalin, baicalein and wogonin did not demonstrate cytotoxic selectivity towards the lung cancer cell lines. The crude extract exhibited higher safety and efficiency than the sole compounds. ${ }^{46}$ Another interesting study suggested that the antitumor potential of the crude extract from a Chinese skullcap root ( $\mathrm{SbE}$ ) against colorectal cancer would increase once baicalin is removed. This result indicated that excluding baicalin from $\mathrm{SbE}$ would induce the generation of an aglycone-rich fraction (ARF) that can markedly inhibit the progress of colorectal cancer. ${ }^{47}$

Gong et al. reported the significant inhibition of polyphenolic extracts on the proliferation and metastasis of lung cancer that occurred due to nicotine induction in A549 and H1299 lung cancer cell lines. The specific extract of skullcap roots, containing baicalin, baicalein and wogonin, could significantly counteract the deleterious changes caused by nicotine exposure, such as the augmentation of proliferation, a remarkable decrease in apoptosis, and the invasive and migratory concomitants. ${ }^{48}$ The polyphenolic extract effectively negated the nicotine-induced changes in the tumor apoptotic and metastatic factors from mRNA to protein levels such as the up-regulated expression of Bcl-2 (B-cell lymphoma 2), Bcl-2/Bax (Bcl-2-associated $\mathrm{X}$ protein) ratio, caspase-3, matrix metalloproteinase (MMP)-2 and MMP-9 and down-regulated expression of Bax. This finally substantiated the anti-inflammatory effect of the skullcap polyphenolic extract on nicotine-exposed lung cancer cells by profound analysis of inflammatory 
markers such as the tumor necrosis factor (TNF)- $\alpha$ and inter-

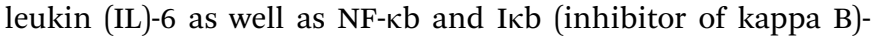
$\alpha$ signals. This confirmed the anti-inflammatory benefits of the skullcap extract on the deterioration of lung cancer. ${ }^{48}$ Peng et al. evaluated the effect of the skullcap polyphenolic extract (SBGE) on the immune and anti-oxidant functions in U14 tumorbearing mice. The administration of SBGE at a high dose (1000 $\mathrm{mg} \mathrm{kg}^{-1}$ ) for 2 weeks caused remarkable immune enhancement and anti-oxidant ability in U14 tumor-bearing mice. These advantages possibly contributed to the tumor inhibition in cervical tissues. ${ }^{49}$ The skullcap polyphenolic extract was also efficient in the proliferation inhibition of human endometrial cancer, and the pharmacological action was similar to that of another Chinese herb Fritillaria cirrhosa. ${ }^{50}$ The treatment with the skullcap polyphenolic extract for endometrial cancer cells resulted in substantial decline in the expression of the isoforms and receptors of the transforming growth factor (TGF) family as well as Smad proteins. The skullcap polyphenolic extract also essentially hindered the proliferation and invasion of the basal and TGF-1-induced cancer cells. The cancer cells were strongly inhibited by the extract due to the abrogation of Snail, Slug, MMPs, v3 integrin, focal adhesion kinase (FAK), and p-FAK expressions. However, the anticancer effects of the polyphenolic extract were remarkably diminished by an inhibitor of TGF-receptor I since the blockage of TGF-1 induced cancer cell invasion. ${ }^{50}$ A high dose of the skullcap polyphenolic extract $\left(200 \mu \mathrm{g} \mathrm{mL}^{-1}\right)$ inhibited ovarian cancer growth and reduced the invasive potential of cancer cells. The treatment of ovarian cancer cells resulted in caspase- 3 activation, $\mathrm{G}(0) / \mathrm{G}(1)$ phase cell cycle arrest, cyclin D1 and D3 down-regulation and p27 induction. ${ }^{51}$ The skullcap polyphenols helped increase the antitumor effect of cisplatin on ovarian cancer, which might reduce the multidrug resistance of tumors. ${ }^{52}$ Hussain et al. also confirmed the efficiency of the crude skullcap polyphenols in the inhibition of ovarian cancer. The use of the extract attenuated the hypoxia-inducible factor (HIF)-1 expression in cancer cell lines, reduced the activation of phosphatidylinositol 3-kinase/protein kinase B (PI3K/AKT) and MAPK/ERK (extracellular-signal-regulated kinase) in ovarian cancer cells, and intensified the anti-cancer effects of cisplatin against ovarian cancer cells by inhibiting the expressions of HIF-1, ATP-binding cassette sub-family G member-1, and $-2 .{ }^{53}$ Park's another research suggested that SBGE should be considered as an effective agent to inhibit the growth of breast cancer. ${ }^{54}$ SBGE significantly induced the apoptosis of human breast cancer cells MCF-7 in the concentration range from 100 to $500 \mathrm{mg} \mathrm{mL}^{-1}$. The $24 \mathrm{~h}$ treatment of SBGE for MCF-7 caused the inhibition of cell proliferation and increased the sub-G1 phase ratio. The following study identified that the suppression of mitochondrial membrane potentials and the apoptotic death of MCF-7 cells were associated with the down-regulation of Bcl-2 and up-regulation of Bax. ${ }^{54}$ Korean researchers also proved that the purified polyphenolic extract (FSB) from Chinese skullcap exhibited an anticancer effect on AGS human gastric cancer cells. The treatment with FSB for the AGS cells obviously inhibited the cell viability in a concentrationdependent manner. Furthermore, significantly down-regulated expressions of pro-caspases-3 and -9 and poly(ADP-ribose) polymerase (PARP) were identified in AGS cells after treatment with FSB accompanied by the subsequent up-regulation of cleaved caspase-3 and cleaved PARP. FSB significantly decreased the mitochondrial membrane potential of the AGS cells and up-regulated the ratio of the mitochondrionassociated proteins Bax and Bcl-xL (B-cell lymphoma-extra large). ${ }^{55}$

\section{Anticancer effects of single skullcap polyphenols}

Here, single polyphenols possessing anticancer activities are defined as individual compounds originating from Chinese skullcap, which are detectable in herbal roots at relatively high amounts. Chinese skullcap polyphenols include specific skullcap polyphenols (baicalein and wogonin homologues) and general polyphenol components (chrysin, oroxylin-A, dihydrooroxylin-A, hispidulin, negletein, scutellarein, scutellarin, etc.). The specific skullcap polyphenols mainly exist in the genus Scutellaria, while the general polyphenol components are not only found in skullcap, but also in other plants. All the polyphenols detected in skullcap roots are listed in Table 1, and the following sections discuss their anticancer activities to obtain integrated generalization of this herbal medicine. In recent years, experts have extensively reviewed the anticancer activities and mechanisms of the baicalein, baicalin, wogonin, and wogonoside compounds $\mathrm{s}^{7, \mathbf{1 8 , 5 6 - 5 9}}$ as well as those of the nonspecific polyphenols such as chrysin ${ }^{\mathbf{6 0 , 6 1}}$ and verbascoside. ${ }^{\mathbf{6 2}}$ Table 2 summarizes the recent advancement in the anticancer studies of baicalein, baicalin, wogonin, and wogonoside against breast cancer, hepatocellular cancer (HCC) and colorectal cancer using animal models. In order to facilitate the understanding of the therapeutic roles of the above-mentioned skullcap polyphenols on various cancers, we, herein, mainly focused on the anti-cancer effects of 12 other polyphenols of skullcap roots than the 6 compounds indicated above as wellreviewed polyphenols.

\section{Anticancer effects of oroxylin-A}

Oroxylin-A is one of the major flavonoids found in the root of Chinese skullcap. Oroxylin-A significantly inhibits the HeLa cell growth in vitro, and its $\mathrm{IC}_{50}$ is $19.4 \mu \mathrm{M}$ after $48 \mathrm{~h}$ treatment. ${ }^{69}$ Moreover, the oral administration of oroxylin-A $\left(80 \mathrm{mg} \mathrm{kg}^{-1 / 2}\right.$ days) for 2 weeks induced significant reduction in tumor volumes and weights of the nude mice inoculated with HeLa cells. ${ }^{69}$ In the bioassay of the HepG2 cells, oroxylin-A induced apoptosis and may serve as a potential, novel drug candidate in human HCC therapy. ${ }^{70}$ Oroxylin-A caused cell apoptosis through the mitochondrial pathway of the HepG2 cells in a mitochondrial permeability transition pore (MPTP)dependent manner, and it also caused the proliferation inhibition of HepG2 in xenograft mice. ${ }^{71}$ Oroxylin-A displayed reliable anticancer activities by killing human primary HCC cells, suppressing the tumor growth in patient-derived tumor 


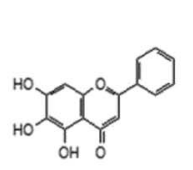

1. Baicalein

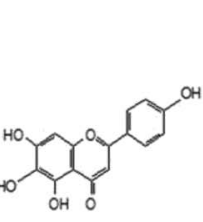

7. Scutellarein

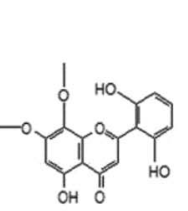

13. Viscidulin-II

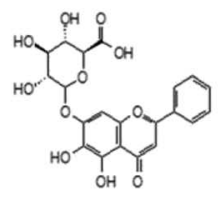

2. Baicalin

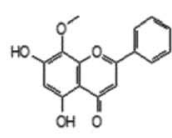

3. Wogonin

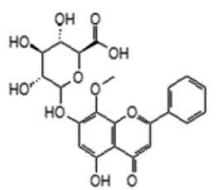

4. Wogonoside

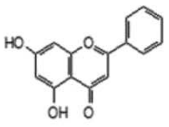

5. Chrysin

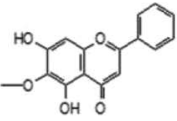

6. Oroxylin-A

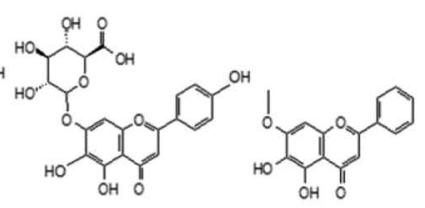

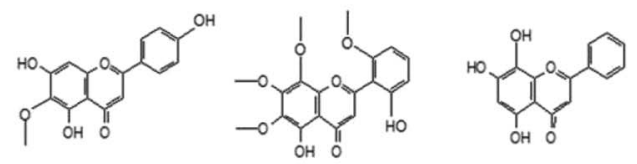

8. Scutellarin

9. Negletein

10. Hispidulin

11. Rivularin

12. Norwogonin

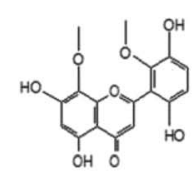

14. Viscidulin-III

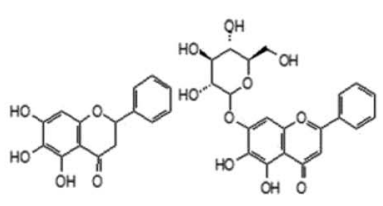

16. Oroxin-A

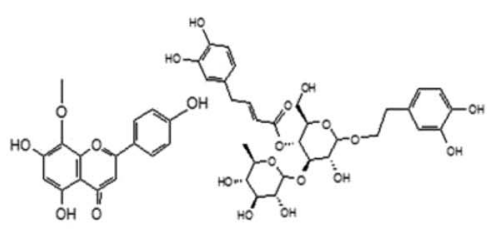

17. 4'-Hydroxywogonin 18. Verbascoside

Fig. 2 Structures of the 18 polyphenols found in Chinese skullcap with anticancer activity.

xenograft models, and slowing down the development of primary hepatoma. ${ }^{72}$ The apoptosis of human colon cancer cells induced by oroxylin-A is regulated by the uncoupling protein 2 (UCP2), which triggers the MPTP opening and promotes the apoptosis in CaCo-2 cells since UCP2 plays a key role in the mitochondrial apoptotic pathway. ${ }^{73}$ Oroxylin-A triggers the mitochondrial translocation of p53 and leads to mitochondrial dysfunction in human colon cancer cells since it induces p53 mitochondrial translocation, inhibits the activity of SOD2 and promotes the formation and mitochondrial translocation of the p53-Recql4 complex. $^{74}$ Similar positive results on oroxylin-A were obtained from a test towards colorectal cancer, indicating it to be a potent drug candidate in the prevention of colorectal cancer. ${ }^{75}$ Oroxylin-A could inactivate HIF1 $\alpha$ and reprogram the fatty acid metabolism in HCT116 cells by decreasing the intracellular fatty acid levels and enhancing fatty acid oxidation. Furthermore, the rapid decrease in the fatty acid level inactivated the nuclear translocation of $\beta$-catenin and inhibited the Wnt pathway, resulting in cancer cell cycle arrest in the G2/M phase. ${ }^{75}$ Oroxylin-A increased the apoptotic sensitivity of the HT-29 cells to 5-fluorouracil (5-FU). This effect may be attributed to the significant elevation of the reactive oxygen species (ROS) in HT-29 cells, which subsequently inhibited the COX-2 expression and enhanced the susceptibility of the HT-29 cells to 5 -FU. ${ }^{76}$ Oroxylin-A inhibited the glycolysis-dependent proliferation of breast cancer cells through the suppression of HIF1 $\alpha$ stabilization via SIRT3 (Sirtuin 3) activation. This preclinical information on oroxylin-A proves that it is a good choice in cancer therapies aiming at SIRT3 stimulation. ${ }^{77}$ Oroxylin-A does not directly affect the transcription of wt-p53 but suppresses the Mdm2-mediated degradation of $\mathrm{p} 53$ via down-regulating the $\mathrm{Mdm} 2$ gene transcription in wt-p53 cancer cells. In vivo, oroxylin-A inhibits the tumor growth of nude mice inoculated with MCF-7 or HCT116 cells. ${ }^{78}$ Oroxylin-A suppresses MDA-MB-435 cell adhesion to a fibronectin-coated substrate in a concentration-dependent manner, indicating its potential in anti-metastasis in vitro. ${ }^{79}$ Oroxylin-A might be developed as a metastatic drug to improve the treatment of non-small cell lung carcinoma (NSCLC) as its anticancer effects were observed from a study, in which oroxylin-A played a role in anoikis sensitization and glycolysis inhibition. ${ }^{80}$ Furthermore, oroxylinA ( $80 \mathrm{mg}$ per $\mathrm{kg}$ per day, for 45 days) could inhibit the lung metastasis of the A549 cells in nude mice. ${ }^{80}$ Oroxylin-A also inhibited migration and invasion in Snail-expressing 95-D and A549 lung cancer cells, whereas it had a limited effect on the non-Snail-expressing GLC-82 cells. ${ }^{81}$ Oroxylin-A inhibited the generation of Treg cells in a lung cancer environment by decreasing the response of T cells to TGF- $\beta 1$ and reducing the secretion of TGF- $\beta 1$ in lung cancer cells via the NF- $\kappa B$ pathway. ${ }^{82}$

\section{Anticancer effects of scutellarein and scutellarin}

The detectable polyphenols in the root of Chinese skullcap, i.e., scutellarein and its 7-O-glucuronide derivative (scutellarin) are two important phytochemicals possessing anti-cancer activities and have also been well studied as adjuvant chemotherapy agents. Scutellarein has anti-proliferative activities against multiple cancer lines and diminishes the oxidative stress and tumor development of murine ascitic lymphoma and inflammatory hepatocellular carcinoma. Experimental proofs suggest that scutellarein has an excellent potential in inhibiting the progress of tumors by modulating the sprouting neovasculature and $40 \mathrm{kDa}$ DNA fragmentation factor-mediated cell death. ${ }^{83}$ Scutellarein attenuates proliferation in the lung cancer A549 cell line through the epidermal growth factor receptor pathway 
Table 2 In vivo anti-tumor effects of baicalein, baicalin, wogonin and wogonoside towards breast cancer, hepatocellular cancer and colorectal cancer

\begin{tabular}{|c|c|c|c|c|c|}
\hline Cancer types & Compounds & Animal models & Dose $\&$ administration & Effectiveness & Reference \\
\hline \multirow[t]{6}{*}{ Breast cancer } & Baicalein & $\begin{array}{l}\text { MDA-MB- } 231 \text { cell } \\
\text { xenograft in nude } \\
\text { mouse }\end{array}$ & $\begin{array}{l}50 \text { or } 100 \mathrm{mg} \text { per } \mathrm{kg} \text { per day, } \\
\text { i.g. for } 15 \text { days }\end{array}$ & $\begin{array}{l}\text { Cancer metastasis suppressed by } \\
\text { inhibition of EMT via downregulation of } \\
\text { SATB1 and Wnt//-catenin pathway }\end{array}$ & 56 \\
\hline & Baicalein & $\begin{array}{l}\text { MDA468 cell xenograft } \\
\text { in SCID-Bg mice }\end{array}$ & $\begin{array}{l}20 \mathrm{mg} \text { per } \mathrm{kg} \text { per day, i.p. for } 5 \\
\text { week }\end{array}$ & $\begin{array}{l}\text { Inhibition of tumor growth without } \\
\text { toxicity to the host and increased DDIT4 }\end{array}$ & 56 \\
\hline & Baicalin & $\begin{array}{l}\text { MDA-MB-231 cells in } \\
\text { xenograft mouse model }\end{array}$ & $\begin{array}{l}100 \mathrm{mg} \text { per kg per day, i.p. for } 8 \\
\text { weeks }\end{array}$ & $\begin{array}{l}\text { Suppression in the tumorigenicity of } \\
\text { cancer cells by down-regulating MMP-2, } \\
\text { MMP-9, uPA and uPAR expressions } \\
\text { through the interruption of p38 MAPK } \\
\text { signaling pathway }\end{array}$ & 63 \\
\hline & Wogonin & $\begin{array}{l}\text { MCF-7 xenograft in } \\
\text { BALB/c nude mice }\end{array}$ & $\begin{array}{l}30 \text { or } 60 \mathrm{mg} \text { per } \mathrm{kg} \text { per day, i.v. } \\
\text { for } 21 \text { days }\end{array}$ & $\begin{array}{l}\text { Significant reduction in tumor size with } \\
60 \mathrm{mg} \mathrm{kg}^{-1} \text { dose }\end{array}$ & 64 \\
\hline & Wogonin & $\begin{array}{l}\text { MDA-MB-231 cells } \\
\text { induced with } 1 \mu \mathrm{g} \mathrm{mL}^{-1} \\
\text { of LPS for } 24 \mathrm{~h} \text { prior to } \\
\text { being xenografted in } \\
\text { BALB/c nude mice }\end{array}$ & $\begin{array}{l}20 \mathrm{mg} \text { per } \mathrm{kg} \text { per day, i.v. for } 21 \\
\text { days }\end{array}$ & $\begin{array}{l}\text { Suppression in LPS-enhanced } \\
\text { invasiveness of cancer cell through } \\
\text { inhibition of 5-LO/BLT2 cascade }\end{array}$ & 65 \\
\hline & Wogonoside & $\begin{array}{l}\text { MDA-MB- } 231 \text { cell } \\
\text { xenograft in nude } \\
\text { mouse }\end{array}$ & $\begin{array}{l}80 \mathrm{mg} \text { per } \mathrm{kg} \text { per day, i.p. for } 90 \\
\text { days }\end{array}$ & $\begin{array}{l}\text { Obvious suppressions in growth and } \\
\text { metastasis of breast tumor }\end{array}$ & 66 \\
\hline \multirow[t]{6}{*}{$\begin{array}{l}\text { Hepatocellular } \\
\text { cancer }\end{array}$} & Baicalein & $\begin{array}{l}\text { SK-Hep1 cell xenograft } \\
\text { in athymic BALB/c nude } \\
\text { mice }\end{array}$ & $\begin{array}{l}5,10,20 \mathrm{mg} \text { per } \mathrm{kg} \text { per day; i.p. } \\
\text { for } 32 \text { days }\end{array}$ & $\begin{array}{l}\text { Decrease of solid tumor mass and } \\
\text { number reduction of PK Ca-positive cells }\end{array}$ & 58 \\
\hline & Baicalein & DEN-induced rat model & $\begin{array}{l}250 \mathrm{mg} \mathrm{kg}{ }^{-1} \text {, b.wt., i.g. for } 2 \\
\text { weeks }\end{array}$ & $\begin{array}{l}\text { Reduction in neoplastic nodules by } \\
\text { inhibition of } 12 \text {-LOX }\end{array}$ & 58 \\
\hline & Baicalein & $\begin{array}{l}\text { HepG2 cell xenograft in } \\
\text { male BALB/c nude mice }\end{array}$ & $\begin{array}{l}20 \mathrm{mg} \text { per } \mathrm{kg} \text { per day, orally, } \\
\text { for } 3 \text { weeks }\end{array}$ & $\begin{array}{l}\text { Suppression in tumor growth by } \\
\text { inhibiting the MEK-ERK signaling and } \\
\text { induction of the intrinsic apoptosis }\end{array}$ & 58 \\
\hline & Baicalein & $\begin{array}{l}\text { MHCC } 97 \mathrm{H} \text { cells } \\
\text { xenograft in male BALB/ } \\
\text { c nude mice }\end{array}$ & $\begin{array}{l}10 \mathrm{mg} \text { per } \mathrm{kg} \text { per day, orally } 35 \\
\text { days }\end{array}$ & Metastasis inhibition of tumor cell & 58 \\
\hline & Baicalein & $\begin{array}{l}\text { H22 cell xenograft in } \\
\text { ICR mice }\end{array}$ & $\begin{array}{l}50 \text { and } 100 \mathrm{mg} \text { per } \mathrm{kg} \text { per day, } \\
\text { i.p. for } 13 \text { days }\end{array}$ & $\begin{array}{l}\text { Inhibition in tumor growth without } \\
\text { causing obvious adverse effects on weight } \\
\text { or liver and spleen weight }\end{array}$ & 58 \\
\hline & Wogonin & $\begin{array}{l}\text { SMMC- } 7721 \text { xenograft } \\
\text { in BALB/c nude mice }\end{array}$ & $\begin{array}{l}30 \mathrm{mg} \mathrm{kg}^{-1} \text { of wogonin or } \\
30 \mathrm{mg} \mathrm{kg}^{-1} \text { of wogonin pulse } \\
10 \mathrm{mg} \mathrm{kg}^{-1} \text { of } 5 \text {-FU, i.v, for } 2 \\
\text { days }\end{array}$ & $\begin{array}{l}30 \mathrm{mg} \mathrm{kg} \mathrm{kg}^{-1} \text { of wogonin induced } 46 \% \\
\text { tumor inhibition rate, while } 30 \mathrm{mg} \mathrm{kg} \\
\text { of wogonin plus } 10 \mathrm{mg} \mathrm{kg}^{-1} \text { of } 5-\mathrm{FU} \\
\text { induced } 91.69 \% \text { of tumor inhibition rate }\end{array}$ & 64 \\
\hline \multirow[t]{6}{*}{$\begin{array}{l}\text { Colorectal } \\
\text { cancer }\end{array}$} & Baicalein & $\begin{array}{l}\text { AOM/DSS-induced } \\
\text { colon cancer }\end{array}$ & $\begin{array}{l}1,5,10 \mathrm{mg} \text { per } \mathrm{kg} \text { per day, } \\
\text { orally for } 16 \text { weeks }\end{array}$ & $\begin{array}{l}\text { Significant decrease in the incidence of } \\
\text { tumor formation with inflammation }\end{array}$ & 56 \\
\hline & Baicalein & $\begin{array}{l}\text { HCT- } 116 \text { cell xenograft } \\
\text { in athymic nude mice }\end{array}$ & $\begin{array}{l}30 \mathrm{mg} \mathrm{kg}^{-1}, \text { i.p. every other day } \\
\text { for } 4 \text { weeks }\end{array}$ & $\begin{array}{l}\text { More significant inhibition of tumor } \\
\text { growth than its parent compound of } \\
\text { baicalin }\end{array}$ & 56 \\
\hline & Baicalein & $\begin{array}{l}\text { HT- } 29 \text { cells xenografts } \\
\text { in nude mice }\end{array}$ & $\begin{array}{l}10 \mathrm{mg} \mathrm{kg}^{-1} \text {, orally three times } \\
\text { every week for } 43 \text { days }\end{array}$ & $\begin{array}{l}\text { Significant decrease of tumor weights } \\
\text { and volumes without toxicity }\end{array}$ & 56 \\
\hline & Baicalin & $\begin{array}{l}\text { HT- } 29 \text { cells xenografts } \\
\text { in nude mice }\end{array}$ & $\begin{array}{l}50 \text { and } 100 \mathrm{mg} \text { per } \mathrm{kg} \text { per day, } \\
\text { i.p. for } 21 \text { days }\end{array}$ & $\begin{array}{l}\text { Effective induction and enhancement of } \\
\text { tumor cell apoptosis in a dose-dependent } \\
\text { manner and suppression of tumor } \\
\text { growth in mice }\end{array}$ & 67 \\
\hline & Wogonin & $\begin{array}{l}\text { Human colon cancer } \\
\text { cell HCT } 116 \text { xenograft } \\
\text { in BALB/c nude mice }\end{array}$ & $\begin{array}{l}30 \text { or } 60 \mathrm{mg} \mathrm{kg}^{-1} \text {, i.v, } 2 \text { days per } \\
\text { dose, for } 3 \text { weeks }\end{array}$ & $43-52 \%$ of tumor inhibition rate & 64 \\
\hline & Wogonoside & $\begin{array}{l}\text { Azoxymethane-initiated } \\
\text { and dextran sulfate } \\
\text { sodium (AOM/DSS)- } \\
\text { promoted colorectal } \\
\text { carcinogenesis mouse } \\
\text { model }\end{array}$ & $\begin{array}{l}100 \mathrm{mg} \text { per } \mathrm{kg} \text { per day, i.g. for } \\
105 \text { days }\end{array}$ & $\begin{array}{l}\text { Significant reduction in disease severity, } \\
\text { low tumor incidence and inhibition in } \\
\text { development of colorectal adenomas }\end{array}$ & 68 \\
\hline
\end{tabular}


by mediating ERK and NF- $\kappa$ B. The cell proliferation of A549 can be obviously suppressed by using $50 \mu \mathrm{M}$ scutellarein in $24 \mathrm{~h}$ and/or $48 \mathrm{~h}$ of treatment. ${ }^{84}$ Scutellarein possesses the ability to attenuate the development of fibrosarcoma and inhibits cancer cell metastasis. ${ }^{\mathbf{8 5}}$ The proliferation rate of human fibrosarcoma HT1080 cells can be significantly suppressed under scutellarein intervention through apoptosis induction. Moreover, an in vivo experiment using Balb/c nude mice revealed that their tumor volumes and weights markedly reduced after 20 days of scutellarein injection ( $0.5 \mathrm{mg}$ per $\mathrm{kg}$ per day). Scutellarein potently inhibited cancer cell migration and invasion and decreased the expression and activity of MMP-2, -9 and -14 due to the downregulation of NF- $\kappa \mathrm{B}$ activation. ${ }^{85}$ Scutellarein displays strong anti-proliferative activities to HepG2 cells in vitro. ${ }^{\mathbf{8 6}}$ This chemical can interact with the key factors expressed on the cell surface of cancer tumors, such as pyruvate kinase M2, and inhibit the cytosolic activity to decrease glycolytic metabolism. It also participates in regulating the cell cycle and apoptotic proteins by activating the MEK/ERK/PIN1 signaling pathway to promote the nuclear translocation of pyruvate kinase M2. ${ }^{87}$

Scutellarin is a metabolite of scutellarein and has been reported to have stronger anticancer activity than scutellarein. ${ }^{\mathbf{8}}$ Scutellarin can be developed as a promising anti-tumor drug to treat colon cancer since it shows anti-proliferative and proapoptotic effects on human colon cancer HCT-116 cells. The exposure of HCT-116 cells to scutellarin decreased cell viability in a dose- and time-dependent manner and also induced apoptotic transformation of the cancer cells via the potential regulation of p53 and $\mathrm{Bcl}-2 / \mathrm{Bax}$ expressions. ${ }^{89}$ Scutellarin is considered as a new sensitizing agent for helping 5-FU-evoked apoptosis of colon cancer HCTI 16 cells by the enhancement of the caspase- 6 activation in a p53-dependent manner. ${ }^{90}$ In another in-depth investigation, scutellarin suppressed the colorectal cancer cell viability and colony formation in vitro and remarkably reduced the tumor growth in mouse xenografts. ${ }^{\mathbf{1 1}}$ Evidences indicate that scutellarin suppresses angiogenesis induction in colorectal cancer cells and restrains micro-vessel formation while inhibiting the migration and tube formation in human umbilical vascular endothelial cells. ${ }^{91}$ Scutellarin benefits the curative molecular therapy for NSCLC due to the significant suppression in the proliferation of the NSCLC cells, which induces cell apoptosis and triggers autophagy in vivo. The oral administration of scutellarin ( $60 \mathrm{mg}$ per $\mathrm{kg}$ per day) once a day for 3 weeks significantly inhibited tumor growth in NSCLC xenografts in nude mice, increased the LC3-II and p-ERK1/2 levels, and suppressed p-AKT signals in mice tumors. ${ }^{92} \mathrm{Scu}-$ tellarin could accelerate the sensitization of the A549/DDP cells to cisplatin by enhancing apoptosis and autophagy, demonstrating that the combination of cisplatin with scutellarin would be a potential therapeutic strategy for NSCLC patients. ${ }^{93}$ Scutellarin is more effective than other skullcap polyphenols in the treatment of liver cancer based on many evidences. Scutellarin notably suppresses the HepG2 proliferation in a concentration- and time-dependent manner. It is capable of inducing strong cell apoptosis via STAT3 (signal transducer and activator of transcription 3) signals, which provides strong support for the use of scutellarin as an alternative therapy for
HCC. ${ }^{94}$ Li et al. proved that scutellarin prompted autophagymediated cell death in HepG2 cells. ${ }^{95}$ Furthermore, scutellarin could suppress HCC cell metastasis in vivo and inhibit the migration and invasion of cancer cells in vitro by downregulating the STAT3/Girdin/AKT signaling. The administration of scutellarin (50 mg per $\mathrm{kg}$ per day) for 35 days significantly mitigated the lung and intrahepatic metastasis of HCC tumors in vivo. ${ }^{96}$ In oral squamous cell carcinoma cells (HSC-4 and SAS), scutellarin attenuated tumor cell proliferation and migration and regulated cell adhesion; its anticancer efficiency was closely related to the up-regulation of E-cadherin and downregulation of integrin $\alpha(\mathrm{v}) \beta(6)$. Scutellarin caused significant inhibition in tongue cancer cell proliferation at $75 \mu \mathrm{M}$ and decreased the cell motility to $46.3 \%$ and $44 \%$ in HSC- 4 and SAS at $15 \mu \mathrm{M}$, respectively. At $3 \mu \mathrm{M}$ of concentration, it could enhance the E-cadherin expression by $37.9 \%$ and $52 \%$, decrease the integrin $\alpha(v) \beta(6)$ expression by $45.4 \%$ and $47.2 \%$ and increase the desmoplakin levels by $79.9 \%$ and $74.5 \%$ in HSC-4 and SAS cells, respectively. ${ }^{97}$ Another study indicated the strong therapeutic effect of scutellarin towards human tongue squamous carcinoma by inhibiting the invasion and metastasis of SAS cells. The administration of scutellarin to SAS-implanted nude mice suppressed tumor cell proliferation, induced apoptosis, and regulated the expressions of MMP-2 and -9 and integrin $\alpha(\mathrm{v}) \beta(6)$ at the mRNA and protein levels in vivo. ${ }^{98}$ Besides the above experimental examples, there are several reports concerning the anticancer effect of scutellarin for cancer types, such as human breast cancer (MCF-7 cell), ${ }^{99}$ renal cell carcinoma (ACHN and 786-O cells), ${ }^{\mathbf{1 0 0}}$ prostate cancer (PC3 cell), ${ }^{101}$ and human lymphoma (Namalwa cell). ${ }^{102}$ Scutellarin is effective against these cancer types, and its inhibitory effects have been roughly confirmed in the past several years.

\section{Anticancer effects of hispidulin}

Hispidulin is another flavone chemical with significant anticancer activity and is also detectable in the root of Chinese skullcap. Hispidulin was first demonstrated as a potential chemopreventive agent as it could inhibit the metabolism of the carcinogen benzo $(a)$ pyrene in hamster embryo cells in cell culture. ${ }^{103}$ Hispidulin induces the cell apoptosis of human ovarian cancer through TNF-related apoptosis-inducing ligand (TRAIL) signals since it converts TRAIL-resistant cells into TRAIL-sensitive cells. The mechanism involves the high activation of caspases- 8 and -3 and the consequent PARP cleavage caused by the down-regulation of myeloid cell leukemia-1, Bcl-2, and Bcl-xL. Tumor sensitization resulting from the addition of hispidulin is controlled by the adenosine monophosphate (AMP)-activated protein kinase (AMPK). ${ }^{104}$ Hispidulin at $20 \mathrm{mg}$ $\mathrm{kg}^{-1}$ of daily dosage for 35 days significantly inhibited the growth of human pancreatic tumor xenograft in C57/BL6 mice, and the effect was accompanied by potent inhibition on angiogenesis. Hispidulin could suppress VEGF (vascular endothelial growth factor)-induced microvessel sprouting of rat aortic rings and corneal neovascularization in the xenograft mice. The angiogenesis inhibition reduced the cancer cell migration and invasion induced by VEGF and stopped the 
capillary-like structure formation of human umbilical vein endothelial cells in a dose-dependent manner because hispidulin could target the VEGF receptor-2-mediated PI3K/AKT signaling pathway. ${ }^{29}$ Hispidulin is anticipated as a potential agent in combination therapy for gastric cancer in the future due to the fact that it inhibits the growth of AGS gastric cancer cells. The incubation of hispidulin in AGS cells prompted a high expression of the NAG-1 gene and down-regulation of COX-2 expression and induced G(1)/S phase arrest and cell apoptosis in a time- and concentration-dependent manner. The anticancer effect might be attributed to the efficient activation of ERK1/2 signaling. ${ }^{105}$ Hispidulin is also suitable for liver cancer therapy because it induces HepG2 cell death in a dose- and time-dependent manner. Also, hispidulin has no toxic effect on normal human liver cells at the indicated concentration. The cancer cell apoptosis induced by hispidulin might be mediated through mitochondrial dysfunction and the inhibition of the PI3K/AKT signaling pathway. The result was accompanied by a decreased Bcl-2/Bax ratio, disrupted mitochondrial membrane potential and increased release of cytochrome $\mathrm{C}$ and activated caspase- $3 .{ }^{106}$ Another study indicates that the hispidulin treatment of HepG2 cells increases the intracellular ROS and enhances the mRNA level expression and activities of antioxidant enzymes and the glutathione/oxidized glutathione ratio, thus leading to the decrease in cancer cells with multidrug resistance. ${ }^{107}$ Hispidulin causes the induction of apoptosis and blockade of growth and cell cycle progression in gallbladder cancer cells (GBC). The hispidulin-exerted anti-gallbladder cancer effect involves the suppression of HIF-1 $\alpha$-AMPK signaling because it represses the expression of the HIF-1 $\alpha$ protein in a dose-dependent manner without affecting the HIF$1 \alpha$ mRNA expression. Moreover, hispidulin sensitizes the GBC tumor cells to gemcitabine and 5-FU by down-regulating HIF1a/P-gp signaling. ${ }^{108}$ In colorectal cancer, hispidulin exhibits antitumor activity by inhibiting the expression of protooncogene serine/threonine-protein kinase 1 and the subsequent Janus kinase-2/STAT3 signaling due to the generation of ROS. Furthermore, in vivo studies show that hispidulin can significantly inhibit tumor growth and metastasis in a mouse inoculated with colorectal cancer cells. ${ }^{109}$ Hispidulin can attenuate the complication of colorectal cancer (CRC) named as "circular chemorepellent-induced defects" caused by the penetration of cancer cells in the blood micro-vessel endothelia, leading to metastasis. ${ }^{110}$

\section{Anticancer effects of neobaicalein and rivularin}

Neobaicalein is also known as skullcap flavone II. The anticancer effect of neobaicalein against prostate cancer was first proposed in a study aiming to identify the active chemical constituents in Chinese skullcap. ${ }^{111}$ Neobaicalein could inhibit the proliferation of prostate cancer cells when used in combination with other notable polyphenols such as baicalein and wogonin. ${ }^{111}$ The administration of neobaicalein combinations (20 $\mathrm{mg}$ per $\mathrm{kg}$ per day, p.o.) decreased the amplification of prostate cancer xenografts in nude mice by $55 \%$ at 2 weeks as compared with that for placebo. This treatment also delayed the average time from 16 to 47 days in achieving approximate 1000 $\mathrm{mm}^{3}$ of tumor volume. Sang et al. ${ }^{112}$ conceived a functional estrogen receptor bioassay-guided method that led to the fractionation and identification of neobaicalein as the strongest constituent in the Chinese herbal preparation named PC SPES together with two other flavanones, indicating that neobaicalein has estrogenic activity besides an anti-prostate cancer action. Neobaicalein exerts cytotoxic and pro-apoptotic activities on HeLa cancer cells. ${ }^{113}$ The $\mathrm{IC}_{50}$ value of neobaicalein against HeLa cells is $46.62 \mu \mathrm{M}$ after $48 \mathrm{~h}$ of treatment in a bioassay, which is even better than that of wogonin $(79.34 \mu \mathrm{M})$. Neobaicalein can accelerate the apoptotic death of K562 and HL-60 cancer cells. ${ }^{114}$ Neobaicalein strongly suppresses the phosphorylation of STAT3 and therefore is anticipated as a new anticancer candidate. ${ }^{115}$ Jia et al. developed a novel on-line bioaffinity chromatography system to rapidly screen potential anti-hepatoma ingredients from various herbal medicines. Neobaicalein and rivularin were well retained in the HepG2/ CMC column as active anticancer agents, suggesting their potentials in the inhibition of HepG2 cells. The speculation was subsequently confirmed by an in vitro anti-tumor test, and the $\mathrm{IC}_{50}$ values of neobaicalein and rivularin against HepG2 cells were close to those of wogonin and oroxylin-A. ${ }^{116}$ Rivularin has also been evaluated for its cytotoxic activity in three cancer cell lines including A549, Hep3B and HeLa and has been compared with twelve other well-known active compounds. Rivularin exhibited the most potent cytotoxic activity towards A549 (0.04 $\mu \mathrm{M}$ of $\left.\mathrm{IC}_{50}\right)$ and showed a moderate inhibitory effect on Hep3B $\left(\mathrm{IC}_{50}=0.82 \mu \mathrm{M}\right)$, indicating that this compound is more suitable for development as a therapeutic agent for lung cancers. ${ }^{117}$

\section{Anticancer effects of other active polyphenols}

Dihydrobaicalein, viscidulin-II, viscidulin-III, negletein, oroxinA and $4^{\prime}$-hydroxywogonin are trace polyphenols in the skullcap root but they definitely exhibit anticancer potentials. To date, some studies have been reported on their anticancer actions. However, it is necessary to further explore their associating pharmacological actions and mechanisms. Dihydrobaicalein and viscidulin II isolated from Chinese skullcap were subjected to an anticancer assay for inhibiting polo-like kinase (PLK), which is very important in cancer therapy. ${ }^{118}$ Dihydrobaicalein exhibited high PLK-1 inhibitory activity, but viscidulin-II showed high selectivity to PLK-2 instead of -1 . The treatment with the two compounds decreased the mitotic cell population in Hep3B cells as a result of the inhibition of mitotic progression because of PLK suppression. ${ }^{118}$ Viscidulin-III inhibited the proliferation of HL-60, and its $\mathrm{IC}_{50}$ against HL-60 was $17.4 \mu \mathrm{M}$, which was equal to that of wogonin..$^{32}$ In human colon carcinoma Hct116 cells, negletein treatment $(50 \mu \mathrm{M}, 4 \mathrm{~h})$ showed stronger cancer cell inhibition than the treatment with baicalein derivatives because negletein could activate the Nrf2 (NF-E2 p45-related factor 2) signaling pathway. ${ }^{119}$ Wu et al. revealed 
that the structure transformation from baicalein to negletein could enhance the anti-proliferative effect to HL-60 cells. ${ }^{\mathbf{1 2 0}}$ Oroxin-A apparently inhibited the growth of human breast cancer MDA-MB-231 and MCF7 cells through endoplasmic reticulum (ER) stress-mediated senescence. Oroxin-A caused tumor cell cycle arrest at the $\mathrm{G}(2) / \mathrm{M}$ phase and prevented the reorganization of microtubules and actin cytoskeleton, which is associated with the reduction in cellular mitosis. Oroxin-A stimulates differentiation of ER-Tracker Red-positive cells in dosage-dependent manner. It also promotes normal cell population with high galactosidase activity but senescence cancer cells associated heterochromatin foci-positive staining. The oroxin-A treatment led to rise in the intracellular ROS level, promoted the expression of ER stress markers, including ATF4 and GRP78, and increased the phosphorylation of a key stressresponse signaling protein p38 as a result of ER stress-mediated senescence. ${ }^{121}$ Sun et al. suggest $4^{\prime}$-hydroxywogonin as a promising anticancer chemical towards CRC in terms of angiogenesis block. ${ }^{122}$ Intervention with $4^{\prime}$-hydroxywogonin attenuated the proliferation of human CRC cells (SW620) in a concentration- and time-dependent manner after the cells were pretreated with interleukin-6 to induce a strong inflammatory response. In contrast, this intervention had little effect on the viability of normal human intestinal epithelial cells under the same conditions. Moreover, 4'-hydroxywogonin down-regulated the mRNA and protein expressions of VEGF-A in a dose-dependent manner and subsequently prevented the phosphorylation of PI3K and AKT. 4'-Hydroxywogonin can be considered as the PI3K inhibitor, and its effect is very similar to that of wortmannin since its combination with wortmannin produces more significant anticancer effects than that of both single compounds. 4'-Hydroxywogonin inhibits tumor enlargement and impedes angiogenesis in CRC, which is relevant to the down-regulation of the VEGF-A expression by disrupting the PI3K/AKT pathway. ${ }^{122}$

\section{Potential clinical implications and development}

All the above results explain the anticancer roles of Chinese skullcap as a crude extract or after combination with other active reagents, forming some effective formulations to treat various cancers due to the abundance of polyphenols. A popular trend can be formed in the integrated Chinese and Western Medicines to cure cancers by combining the skullcap polyphenols with synthetic chemicals. Although a few clinical trials are focusing on single skullcap polyphenols, the use of entire skullcap roots or extracting total polyphenols as well as combinations with other herbals or chemotherapeutic drugs is promising for cancer therapy in future clinics.

Many preclinical studies have identified that some single skullcap polyphenols, such as baicalein, oroxylin-A and wogonin, can be developed as potential antitumor drugs towards various cancers by targeting multiple signaling pathways. Animal experiments have supported these compounds due to the significant decrease in tumor weights and volumes without toxicity to normal tissues (Table 2). These skullcap root polyphenols are suitable for development against specific cancers, such as breast cancer, ${ }^{77,123-127} \mathrm{CRC}^{75,76,128-130}$ and HCC. ${ }^{58,131-133}$ The phase I or II trials of the selective skullcap polyphenols can be initiated in clinics. In order to promote the clinical translation of skullcap polyphenols, in addition to conventional animal experimental data, other critical issues, such as bioavailability and toxicology, have to be comprehensively investigated before clinical trials. ${ }^{134}$

We should not ignore other polyphenols than the 18 compounds described above being subjected to anticancer studies since the systematic screening for anticancer candidates has not been carried out properly on all skullcap polyphenols at the stage of new drug discovery. This should provide sufficient candidates for anticancer screens or assessment with animal models. The trace skullcap polyphenols are perhaps restricted due to their less content after separation and purification. However, these problems can be solved by synthetic means. ${ }^{120,135,136}$ Furthermore, some skullcap polyphenols, such as dihydrooroxylin-A, norwogonin and 5-hydroxy-7, 8-dimethoxyflavone, have evident antioxidant, ${ }^{36}$ immunomodulatory, ${ }^{137}$ antiviral ${ }^{138}$ and anti-radiation effects, ${ }^{24}$ suggesting that they may have potential in the prevention or treatment of cancers because of the close pathological correlations with cancer. Many compounds detected in the skullcap root are metabolites of some anticancer polyphenols and thus should be anticipated to have stronger activities than the prototypes themselves. Examples include oroxylin-A-7-O-glucuronide, baicalin-methylate, chrysin-8- $C$ - $\beta$-D-glucoside, chrysin-7- $O-\beta-\mathrm{D}-$ glucoside, wogonin-7- $O$ - $\beta$-D-glucuronide, and wogonin-5- $O-\beta$-Dglucoside. It is noticeable that the chemical modifications of these special polyphenols can enhance their efficacy in preclinical studies. Moreover, it is also important to develop novel targeting or delivery systems using appropriate technologies to encapsulate the active skullcap polyphenols and improve their anticancer activities. ${ }^{139}$

\section{Conclusions}

Overall, about 53 polyphenols have been identified in Chinese skullcap roots. These polyphenols form the major active substances and exert their therapeutic roles towards many cancers. This review summarizes the antitumor polyphenols in Chinese skullcap roots. We found that the polyphenolic extract and 18 specific compounds have anticancer characteristics against a broad spectrum of cancers. Active polyphenols always exhibit dose-dependent growth inhibition of cancer cells. Consistent with the previous summary on the 6 polyphenols baicalin, baicalein, wogonin, wogonoside, chrysin and verbascoside, 12 other single compounds also showed growth inhibiting activity towards various cancers, including hepatocellular carcinoma, cholangiocarcinoma, pancreatic carcinoma, urothelial carcinoma, lung cancer and breast cancer. Supplementary information on active polyphenols may help understand the exhaustive roles of Chinese skullcap against various cancers. Furthermore, accumulating the data on polyphenols and anticancer pharmacology can provide a convenient way to 
find novel anticancer drugs or synergists in development and utilization.

\section{Conflicts of interest}

There are no conflicts to declare.

\section{Acknowledgements}

The financial grant of this work has been sponsored by the Jiangsu Overseas Visiting Scholar Program for University Prominent Young \& Middle-aged Teachers and Presidents in 2018 (Approved No. [2018]4156) and the Research Grants Committee of Hong Kong (project codes: 740608, 766211 and 17152116) and Innovation Technology Fund of Hong Kong (ITF, Project code: 260900263). This work also is supported by the Major Project of Natural Science Research in Universities of Jiangsu Province (No. 18KJA360008) and the Talent Upgrading Project form Construction of High-level Universities in Guangzhou city.

\section{References}

1 H. S. Parekh, G. Liu and M. Q. Wei, Mol. Cancer, 2009, 8, 18.

2 E. Haslam, T. H. Lilley, Y. Cai, R. Martin and D. Magnolato, Planta Med., 1989, 1-8.

3 M. Carocho and I. C. F. R. Ferreira, Anti-Cancer Agents Med. Chem., 2013, 13, 1236-1258.

4 M. Li-Weber, Cancer Lett., 2013, 332, 304-312.

5 Y. Yuan, L. F. Shuai, S. Q. Chen, L. Q. Huang, S. S. Qin and Z. C. Yang, Z. Naturforsch. C, 2012, 67, 77-85.

6 Q. Zhao, X. Y. Chen and C. Martin, Sci. Bull., 2016, 61, 13911398.

7 C. S. Cheng, J. Chen, H. Y. Tan, N. Wang, Z. Chen and Y. B. Feng, Am. J. Chin. Med., 2018, 46, 25-54.

8 J. W. Fang, W. Y. Wang, S. J. Sun, Y. Wang, Q. H. Li, X. Lu, Z. H. Hao and Y. Y. Zhang, RSC Adv., 2015, 5, 75612-75621.

9 E. H. Kim, B. Shim, S. Kang, G. Jeong, J. S. Lee, Y. B. Yu and M. Chun, J. Ethnopharmacol., 2009, 126, 320-331.

10 T. Y. Yune, J. Y. Lee, C. M. Cui, H. C. Kim and T. H. Oh, J. Neurochem., 2009, 110, 1276-1287.

11 L. Zhang, Z. C. Pu, J. S. Wang, Z. F. Zhang, D. M. Hu and J. J. Wang, Int. J. Mol. Sci., 2014, 15, 8153-8168.

12 K. H. Song, S. H. Lee, B. Y. Kim, A. Y. Park and J. Y. Kim, Phytother. Res., 2013, 27, 244-250.

13 A. Matviychuk, G. Slipchenko, Y. Stoletov, G. Belik, O. Ruban and S. Kutsenko, Turk. J. Pharm. Sci., 2018, 15, 360-363.

14 T. Kumagai, C. Muller, J. C. Desmond, Y. Imai, D. Heber and H. P. Koeffler, Blood, 2004, 104, 4491.

15 Y. Y. Zhang, X. Y. Wang, X. R. Wang, Z. H. Xu, Z. Liu, Q. Ni, X. P. Chu, M. F. Qiu, A. H. Zhao and W. Jia, J. Ethnopharmacol., 2006, 108, 355-360.

16 T. Kumagai, C. I. Muller, J. C. Desmond, Y. Imai, D. Heber and H. P. Koeffler, Leuk. Res., 2007, 31, 523-530.
17 A. M. Y. Lin, Y. H. Ping, G. F. Chang, J. Y. Wang, J. H. Chiu, C. D. Kuo and C. W. Chi, J. Ethnopharmacol., 2011, 134, 884891.

18 M. Li-Weber, Cancer Treat. Rev., 2009, 35, 57-68.

19 H. Y. Wang, S. X. Xu, Y. J. Chen, J. T. F. Wong and H. Xue, Chin. Chem. Lett., 2002, 13, 428-429.

20 A. M. Karimov and E. K. Botirov, Russ. J. Bioorg. Chem., 2017, 43, 691-711.

21 L. Tong, M. X. Wan, L. H. Zhang, Y. H. Zhu, H. Sun and K. S. Bi, J. Pharm. Biomed. Anal., 2012, 70, 6-12.

22 H. Chen, Z. Li, Y. J. Li, X. W. Wu, S. R. Wang, K. Chen, X. X. Zheng, Q. Du and D. Q. Tang, Biomed. Chromatogr., 2015, 29, 1819-1825.

23 H. Y. Jang, K. S. Ahn, M. J. Park, O. K. Kwon, H. K. Lee and S. R. Oh, Int. Immunopharmacol., 2012, 12, 666-674.

24 Y. Kimura and M. Sumiyoshi, J. Pharm. Pharmacol., 2011, 63, 1613-1623.

25 L. L. He, Z. F. Zhang, L. Y. Lu, Y. Liu, S. Li, J. G. Wang, Z. J. Song, Z. G. Yan and J. H. Miao, J. Pharm. Biomed. Anal., 2016, 117, 125-139.

26 A. Wilczanska-Barska, A. Krolicka, D. Glod, M. Majdan, A. Kawiak and M. Krauze-Baranowska, Biotechnol. Lett., 2012, 34, 1757-1763.

27 M. Hirotani, R. Kuroda, H. Suzuki and T. Yoshikawa, Planta, 2000, 210, 1006-1013.

28 B. Liu, R. B. Shi and L. J. Zhu, Zhongguo Zhongyao Zazhi, 2007, 32, 1631-1634.

29 L. He, Y. Wu, L. Lin, J. Wang, Y. Wu, Y. Chen, Z. Yi, M. Liu and X. Pang, Cancer Sci., 2011, 102, 219-225.

30 M. S. Lee, W. K. Oh, B. Y. Kim, S. C. Ahn, D. O. Kang, C. B. Sohn, H. Osada and J. S. Ahn, Planta Med., 2002, 68, 1063-1065.

31 J. Li, Y. Q. Ding, X. C. Li, D. Ferreira, S. Khan, T. Smillie and A. Ikhlas, J. Nat. Prod., 2009, 72, 983-987.

32 M. Sonoda, T. Nishiyama, Y. Matsukawa and M. Moriyasu, J. Ethnopharmacol., 2004, 91, 65-68.

33 Y. Miyaichi, E. Hanamitsu, H. Kizu and T. Tomimori, Chem. Pharm. Bull., 2006, 54, 435-441.

34 S. Gafner, C. Bergeron, L. L. Batcha, C. K. Angerhofer, S. Sudberg, E. M. Sudberg, H. Guinaudreau and R. Gauthier, J. AOAC Int., 2003, 86, 453-460.

35 Q. T. Han, K. Xiao, Y. Cai and S. J. Dai, Zhongguo Zhongyao Zazhi, 2017, 42, 1699-1703.

36 Y. Q. Wang, S. J. Li, G. Zhuang, R. H. Geng and X. Jiang, Biomed. Chromatogr., 2017, 31, 1-10.

37 I. Saracoglu, M. Inoue, I. Calis and Y. Ogihara, Biol. Pharm. Bull., 1995, 18, 1396-1400.

38 Y. A. Choi, O. H. Kang, H. J. Park, J. Tae, D. K. Kim, C. S. Kang, S. C. Choi, K. J. Yun, S. J. Choi, Y. H. Nah, Y. H. Kim, K. H. Bae and Y. M. Lee, Int. J. Mol. Med., 2005, 16, 667-672.

39 H. Y. Wang, K. M. Hui, Y. J. Chen, S. X. Xu, J. T. F. Wong and H. Xue, Planta Med., 2002, 68, 1059-1062.

40 E. J. Park, Y. Z. Zhao, L. H. Lian, Y. C. Kim and D. H. Sohn, Planta Med., 2005, 71, 885-887. 
41 G. Sathishkumar, R. Bharti, P. K. Jha, M. Selvakumar, G. Dey, R. Jha, M. Jeyaraj, M. Mandal and S. Sivaramakrishnan, RSC Adv., 2015, 5, 89869-89878.

42 F. Ye, L. Xui, J. Z. Yi, W. D. Zhang and D. Y. Zhang, J. Altern. Complementary Med., 2002, 8, 567-572.

43 D. Y. Zhang, J. Wu, F. Ye, L. Xue, S. Q. Jiang, J. Z. Yi, W. D. Zhang, H. C. Wei, M. Sung, W. Wang and X. P. Li, Cancer Res., 2003, 63, 4037-4043.

44 F. Ye, S. Q. Jiang, H. Volshonok, J. Wu and D. Y. Zhang, Nutr. Cancer, 2007, 57, 100-110.

45 C. Z. Wang, X. L. Li, Q. F. Wang, S. R. Mehendale and C. S. Yuan, Phytomedicine, 2010, 17, 63-68.

46 J. Y. Gao, W. A. Morgan, A. Sanchez-Medina and O. Corcoran, Toxicol. Appl. Pharmacol., 2011, 254, 221-228.

47 C. Z. Wang, T. D. Calway, X. D. Wen, J. Smith, C. H. Yu, Y. W. Wang, S. R. Mehendale and C. S. Yuan, Int. J. Oncol., 2013, 42, 1018-1026.

48 W. Y. Gong, J. F. Wu, B. J. Liu, H. Y. Zhang, Y. X. Cao, J. Sun, Y. B. Lv, X. Wu and J. C. Dong, Int. J. Oncol., 2014, 44, 15611570.

49 Y. Peng, C. S. Guo, P. X. Li, Z. Z. Fu, L. M. Gao, Y. Di, Y. K. Ju, R. Tian and J. J. Xue, Asian Pac. J. Cancer Prev., 2014, 15, 4129-4133.

50 A. A. Bokhari and V. Syed, J. Cell. Biochem., 2015, 116, 17971805.

51 L. Kavandi, L. R. Lee, A. A. Bokhari, J. E. Pirog, Y. P. Jiang, K. A. Ahmad and V. Syed, Mol. Carcinog., 2015, 54, 368-378.

52 B. Y. Choi, J. C. Joo, Y. K. Lee, I. S. Jang, S. J. Park and Y. J. Park, BMC Complementary Altern. Med., 2017, 17, 1-10.

53 I. Hussain, S. Waheed, K. A. Ahmad, J. E. Pirog and V. Syed, J. Cell. Biochem., 2018, 119, 7515-7524.

54 J. R. Park, M. C. Lee, S. C. Moon, J. Kim, K. T. Ha, E. J. Park, C. Hong, B. D. Seo and B. J. Kim, Mol. Med. Rep., 2017, 16, 2302-2308.

55 V. V. G. Saralamma, H. J. Lee, G. E. Hong, H. S. Park, S. Yumnam, S. Raha, W. S. Lee, E. H. Kim, N. J. Sung, S. J. Lee, J. D. Heo and G. S. Kim, Oncol. Lett., 2017, 14, 607-614.

56 H. Liu, Y. H. Dong, Y. T. Gao, Z. P. Du, Y. T. Wang, P. Cheng, A. M. Chen and H. Huang, Int. J. Mol. Sci., 2016, 17, 1-18.

57 X. Wu, H. J. Zhang, J. M. M. Salmani, R. Fu and B. A. Chen, OncoTargets Ther., 2016, 9, 2935-2943.

58 B. B. Bie, J. Sun, Y. Guo, J. Li, W. Jiang, J. Yang, C. Huang and Z. F. Li, Biomed. Pharmacother., 2017, 93, 1285-1291.

59 Y. Gao, S. A. Snyder, J. N. Smith and Y. C. Chen, Med. Chem. Res., 2016, 25, 1515-1523.

60 E. R. Kasala, L. N. Bodduluru, R. M. Madana, K. V. Athira, R. Gogoi and C. C. Barua, Toxicol. Lett., 2015, 233, 214-225.

61 M. Zeinali, S. A. Rezaee and H. Hosseinzadeh, Biomed. Pharmacother., 2017, 92, 998-1009.

62 K. Alipieva, L. Korkina, I. E. Orhan and M. I. Georgiev, Biotechnol. Adv., 2014, 32, 1065-1076.

63 X. F. Wang, Q. M. Zhou, J. Du, H. Zhang, Y. Y. Lu and S. B. Su, Anti-Cancer Agents Med. Chem., 2013, 13, 923-931.

64 D. L. Huynh, N. Sharma, A. K. Singh, S. S. Sodhi, J. J. Zhang, R. K. Mongre, M. Ghosh, N. Kim, Y. H. Park and D. K. Jeong, Chin. J. Nat. Med., 2017, 15, 15-40.
65 J. H. Go, J. D. Wei, J. I. Park, K. S. Ahn and J. H. Kim, Int. J. Mol. Med., 2018, 42, 1899-1908.

66 Y. Y. Yao, K. Zhao, Z. Yu, H. C. Ren, L. Zhao, Z. Y. Li, Q. L. Guo and N. Lu, J. Exp. Clin. Cancer Res., 2017, 36(1), 103.

67 Y. L. Tao, S. B. Zhan, Y. B. Wang, G. Y. Zhou, H. W. Liang, X. Chen and H. Shen, Sci. Rep., 2018, 8, 14477.

68 Y. Sun, Y. Zhao, X. P. Wang, L. Zhao, W. J. Li, Y. X. Ding, L. Y. Kong, Q. L. Guo and N. Lu, Oncotarget, 2016, 7, 34300-34315.

69 H. N. Li, F. F. Nie, W. Liu, Q. S. Dai, N. Lu, Q. Qi, Z. Y. Li, Q. D. You and Q. L. Guo, Toxicology, 2009, 257, 80-85.

70 R. Mu, Q. Qi, H. Y. Gu, J. Wang, Y. Yang, J. J. Rong, W. Liu, N. Lu, Q. D. You and Q. L. Guo, Mol. Carcinog., 2009, 48, 1159-1169.

71 X. E. Huang, D. Wei, Y. N. Yang, S. Q. Chen, M. Zhu, X. M. Zhang and J. Yu, Int. J. Clin. Exp. Pathol., 2016, 9, 11139-11148.

72 L. B. Wei, Y. Y. Dai, Y. X. Zhou, Z. H. He, J. Y. Yao, L. Zhao, Q. L. Guo and L. Yang, Cell Death Dis., 2017, 8, 1-11.

73 C. Qiao, L. B. Wei, Q. S. Dai, Y. X. Zhou, Q. Yin, Z. Y. Li, Y. M. Xiao, Q. L. Guo and N. Lu, J. Cell. Physiol., 2015, 230, 1054-1063.

74 C. Qiao, N. Lu, Y. X. Zhou, T. Ni, Y. Y. Dai, Z. Y. Li, Q. L. Guo and L. B. Wei, Oncotarget, 2016, 7, 17009-17020.

75 T. Ni, Z. H. He, Y. Y. Dai, J. Y. Yao, Q. L. Guo and L. B. Wei, Cell Death Dis., 2017, 8(6), e2865.

76 J. Ha, L. Zhao, Q. Zhao, J. Yao, B. B. Zhu, N. Lu, X. Ke, H. Y. Yang, Z. Y. Li, Q. D. You and Q. L. Guo, Biochem. Cell Biol., 2012, 90, 521-531.

77 L. Wei, Y. Zhou, C. Qiao, T. Ni, Z. Li, Q. You, Q. Guo and N. Lu, Cell Death Dis., 2015, 6, 1-12.

78 K. Zhao, Y. X. Zhou, C. Qiao, T. Ni, Z. Y. Li, X. T. Wang, Q. L. Guo, N. Lu and L. B. Wei, J. Hematol. Oncol., 2015, 8, 1-18.

79 Y. Sun, N. Lu, Y. Ling, Y. Gao, Y. Chen, L. Wang, R. Hu, Q. Qi, W. Liu, Y. Yang, Q. D. You and Q. L. Guo, Eur. J. Pharmacol., 2009, 603, 22-28.

80 L. B. Wei, Q. S. Dai, Y. X. Zhou, M. J. Zou, Z. Y. Li, N. Lu and Q. L. Guo, Biochim. Biophys. Acta, Gen. Subj., 2013, 1830, 3835-3845.

81 L. B. Wei, Y. Y. Yao, K. Zhao, Y. J. Huang, Y. X. Zhou, L. Zhao, Q. L. Guo and N. Lu, Mol. Carcinog., 2016, 55, 2121-2134.

82 L. Shen, L. L. Zhang, H. Li, X. Liu, X. X. Yu, P. Hu, H. Hui, Q. L. Guo and S. Zhang, Oncotarget, 2017, 8, 49395-49408.

83 P. Thirusangu, V. Vigneshwaran, B. R. V. Avin, H. Rakesh, H. M. Vikas and B. T. Prabhakar, Biochem. Biophys. Res. Commun., 2017, 484, 85-92.

84 C. Y. Cheng, C. C. Hu, H. J. Yang, M. C. Lee and E. S. Kao, Chin. J. Physiol., 2014, 57, 182-187.

85 X. J. Shi, G. F. Chen, X. Q. Liu, Y. Qiu, S. Z. Yang, Y. Zhang, X. X. Fang, C. Zhang and X. Q. Liu, Int. J. Mol. Med., 2015, 35, 31-38.

86 F. Chassagne, M. Haddad, A. Amiel, C. Phakeovilay, C. Manithip, G. Bourdy, E. Deharo and G. Marti, Fitoterapia, 2018, 127, 226-236. 
87 L. You, H. Zhu, C. Wang, F. Wang, Y. J. Li, Y. Li, Y. L. Wang and B. He, Bioorg. Med. Chem. Lett., 2017, 27, 5404-5408.

88 N. E. Wilsher, R. R. Arroo, M. T. Matsoukas, A. M. Tsatsakis, D. A. Spandidos and V. P. Androutsopoulos, Food Chem. Toxicol., 2017, 110, 383-394.

89 N. Yang, Y. Y. Zhao, Z. P. Wang, Y. Liu and Y. Q. Zhang, Mol. Med. Rep., 2017, 15, 929-935.

90 J. Y. Chan, B. K. H. Tan and S. C. Lee, Anticancer Res., 2009, 29, 3043-3047.

91 P. T. Zhu, M. Mao, Z. G. Liu, L. Tao and B. C. Yan, Am. J. Transl. Res., 2017, 9, 5094-5104.

92 C. Y. Sun, C. Y. Li, X. F. Li, Y. Zhu, Z. Q. Su, X. Q. Wang, Q. L. He, G. J. Zheng and B. Feng, J. Cancer, 2018, 9, 3247-3256.

93 C. Y. Sun, Y. Zhu, X. F. Li, X. Q. Wang, L. P. Tang, Z. Q. Su, C. Y. Li, G. J. Zheng and B. Feng, Front. Pharmacol., 2018, 9, 1-11.

94 H. T. Xu and S. Y. Zhang, Phytother. Res., 2013, 27, 15241528.

95 P. Li, N. Geng, R. T. Liu, C. J. An, Y. Bai and J. X. Zheng, Int. J. Clin. Exp. Med., 2016, 9, 13890-13899.

96 Y. Ke, T. H. Bao, X. Wu, H. R. Tang, Y. Wang, J. Y. Ge, B. M. Fu, X. Meng, L. Chen, C. Zhang, Y. Q. Tan, H. T. Chen, Z. T. Guo, F. Ni, X. F. Lei, Z. T. Shi, D. Wei and L. Wang, Biochem. Biophys. Res. Commun., 2017, 483, 509-515.

97 H. X. Li, D. Y. Huang, Z. X. Z. Gao, Y. H. Lv, L. N. Zhang, H. D. Cui and J. H. Zheng, Oncol. Rep., 2010, 24, 1153-1160.

98 H. X. Li, D. Y. Huang, Z. X. Z. Gao, Y. Chen, L. N. Zhang and J. H. Zheng, Int. J. Oncol., 2013, 42, 1674-1681.

99 L. C. Hou, L. Chen and L. Fang, Med. Sci. Monit., 2017, 23, 5130-5138.

100 W. T. Deng, W. Han, T. Fan, X. K. Wang, Z. Cheng, B. Wan and J. L. Chen, Biomed. Pharmacother., 2018, 107, 15051513.

101 C. Gao, Y. L. Zhou, Z. L. Jiang, Y. Zhao, D. J. Zhang, X. Cong, R. F. Cao, H. T. Li and W. R. Tian, Oncol. Rep., 2017, 38, 1491-1499.

102 Y. Z. Feng, S. S. Zhang, J. Tu, Z. F. Cao, Y. Y. Pan, B. X. Shang, R. F. Liu, M. M. Bao, P. D. Guo and Q. S. Zhou, Leuk. Lymphoma, 2012, 53, 2456-2464.

103 Y. L. Liu, D. K. Ho, J. M. Cassady, V. M. Cook and W. M. Baird, J. Nat. Prod., 1992, 55, 357-363.

104 J. M. Yang, C. M. Hung, C. N. Fu, J. C. Lee, C. H. Huang, M. H. Yang, C. L. Lin, J. Y. Kao and T. D. Way, J. Agric. Food Chem., 2010, 58, 10020-10026.

105 C. Y. Yu, K. Y. Su, P. L. Lee, J. Y. Jhan, P. H. Tsao, D. C. Chan and Y. L. Chen, Evid.-Based Complementary Altern. Med., 2013, 2013, 1-12.

106 H. Gao, H. Wang and J. Peng, Cell Biochem. Biophys., 2014, 69, 27-34.

107 C. T. Scoparo, G. Valdameri, P. R. Worfel, F. A. Guterres, G. R. Martinez, S. M. Winnischofer, A. Di Pietro and M. E. Rocha, Mol. Cell. Biochem., 2015, 409, 123-133.

108 H. Gao, J. Xie, J. Peng, Y. Han, Q. Jiang, M. Han and C. Wang, Exp. Cell Res., 2015, 332, 236-246.
109 K. Liu, H. Gao, Q. Wang, L. Wang, B. Zhang, Z. Han, X. Chen, M. Han and M. Gao, Cancer Sci., 2018, 109, 1369-1381.

110 S. Holzner, S. Brenner, A. G. Atanasov, D. Senfter, S. Stadler, C. H. Nguyen, A. Fristiohady, D. Milovanovic, N. Huttary, S. Krieger, Z. Bago-Horvath, O. de Wever, I. Tentes, A. Ozmen, W. Jager, H. Dolznig, V. M. Dirsch, R. M. Mader, L. Krenn and G. Krupitza, Food Chem. Toxicol., 2018, 111, 114-124.

111 M. Bonham, J. Posakony, I. Coleman, B. Montgomery, J. Simon and P. S. Nelson, Clin. Cancer Res., 2005, 11, 3905-3914.

112 S. M. Sang, Z. H. Liu, R. T. Rosen and C. T. Ho, Herbs: Challenges in Chemistry and Biology, 2006, vol. 925, pp. 117-125.

113 Z. Tayarani-Najarani, J. Asili, H. Parsaee, S. H. Mousavi, N. V. Mashhadian, A. Mirzaee and S. A. Emami, Rev. Bras. Farmacogn., 2012, 22, 268-276.

114 M. Boozari, A. Mohammadi, J. Asili, S. A. Emami and Z. Tayarani-Najaran, Environ. Toxicol. Pharmacol., 2015, 39, 307-312.

115 L. D. Chen, D. Y. Lv, X. F. Chen, M. D. Liu, D. Y. Wang, Y. Liu, Z. Y. Hong, Z. Y. Zhu, X. X. Hu, Y. Cao, J. M. Yang and Y. F. Chai, Anal. Chem., 2018, 90, 8936-8945.

116 D. Jia, X. F. Chen, Y. Cao, X. X. Wu, X. Ding, H. Zhang, C. Zhang, Y. F. Chai and Z. Y. Zhu, J. Pharm. Biomed. Anal., 2016, 118, 27-33.

117 P. T. T. Huong, P. T. M. Huong, N. H. Dang, N. V. Thanh, N. X. Cuong, N. H. Nam, P. V. Kiem and C. V. Minh, Lett. Org. Chem., 2017, 14, 310-314.

118 S. U. Woo, H. R. Jang, Y. W. Chin and H. Yim, Planta Med., 2019, 85, 217-224.

119 S. Havermann, Y. Chovolou, H. U. Humpf and W. Watjen, Pharm. Biol., 2016, 54, 1491-1502.

120 J. L. Wu, Y. Y. Chen, X. P. Liu, Y. Gao, J. D. Hu and H. J. Chen, Chem. Biol. Drug Des., 2018, 91, 924-932.

121 J. He, L. S. Du, M. M. Bao, B. Zhang, H. X. Qian, Q. S. Zhou and Z. F. Cao, Anti-Cancer Drugs, 2016, 27, 204-215.

122 D. D. Sun, F. Zhang, J. Qian, W. X. Shen, H. S. Fan, J. N. Tan, L. Li, C. L. Xu, Y. Yang and H. B. Cheng, Chem.-Biol. Interact., 2018, 296, 26-33.

123 K. Zhao, L. B. Wei, H. Hui, Q. S. Dai, Q. D. You, Q. L. Guo and N. Lu, PLoS One, 2014, 9, 1-12.

124 Y. J. Huang, K. Zhao, Y. Hu, Y. X. Zhou, X. W. Luo, X. R. Li, L. B. Wei, Z. Y. Li, Q. D. You, Q. L. Guo and N. Lu, Mol. Carcinog., 2016, 55, 1598-1612.

125 X. C. Ma, W. J. Yan, Z. J. Dai, X. Y. Gao, Y. A. Ma, Q. T. Xu, J. T. Jiang and S. Q. Zhang, Drug Des., Dev. Ther., 2016, 10, 1419-1441.

126 Q. Wu, W. H. Li, T. T. Zhang, S. Zhu, J. J. Li, J. Wu, X. Li, C. Chen, S. R. Sun and C. H. Wang, Int. J. Clin. Exp. Pathol., 2016, 9, 684-694.

127 Y. Gao, H. Liu, H. Z. Wang, H. L. Hu, H. J. He, N. Gu, X. Han, Q. Guo, D. Liu, S. Cui, H. J. Shao, C. J. Jin and Q. Wu, Int. J. Oncol., 2018, 53, 2727-2736.

128 W. C. Chen, T. H. Kuo, Y. S. Tzeng and Y. C. Tsai, Molecules, 2012, 17, 3844-3857. 
129 L. C. He, N. Lu, Q. S. Dai, Y. Zhao, L. Zhao, H. Wang, Z. Y. Li, Q. D. You and Q. L. Guo, Toxicology, 2013, 312, 36-47.

130 C. Z. Wang, C. F. Zhang, L. N. Chen, S. Anderson, F. Lu and C. S. Yuan, Int. J. Oncol., 2015, 47, 1749-1758.

131 L. D. Ma, S. H. Wen, Y. Zhan, Y. J. He, X. S. Uu and J. K. Jiang, Planta Med., 2008, 74, 245-251.

132 L. Zhao, Y. Y. Sha, Q. Zhao, J. Yao, B. B. Zhu, Z. J. Lu, Q. D. You and Q. L. Guo, Biochem. Cell Biol., 2013, 91, 221-229.

133 Y. H. Zheng, L. H. Yin, T. H. M. Grahn, A. F. Ye, Y. R. Zhao and Q. Y. Zhang, Phytother. Res., 2014, 28, 1342-1348.

134 Q. Wang, R. Shi, Y. Dai, Y. Y. Li, T. M. Wang, Y. M. Ma and N. N. Cheng, RSC Adv., 2018, 8, 3364-3373.
135 G. H. He, Y. Gao, C. L. Li, G. L. Wu, Y. Z. Li, L. R. Dong, C. C. Huang and H. J. Chen, Tetrahedron Lett., 2016, 57, 2001-2005.

136 Y. M. Liu, X. D. Song, J. Ma, J. He, X. Zheng, X. Y. Lei, G. R. Jiang, Z. H. Zhao and X. Pan, Chem. Res. Chin. Univ., 2014, 30, 925-930.

137 P. J. Tsai, W. C. Huang, M. C. Hsieh, P. J. Sung, Y. H. Kuo and W. H. Wu, Molecules, 2016, 21, 1-11.

138 H. J. Choi, H. H. Song, J. S. Lee, H. J. Ko and J. H. Song, Biomol. Ther., 2016, 24, 552-558.

139 X. Y. Fang, X. L. Wu, C. E. Li, B. W. Zhou, X. Y. Chen, T. F. Chen and F. Yang, $R S C$ Adv., 2017, 7, 8178-8185. 